\title{
Heavy metals and sulphur in mosses from southern Spitsbergen
}

\author{
KRYSTYNA GRODZIŃSKA and BARBARA GODZIK
}

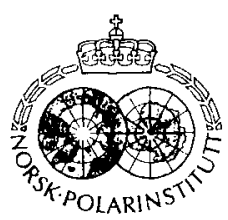

Grodzińska, K. \& Godzik, B. 1991: Heavy metals and sulphur in mosses from southern Spitshergen. Polur Research 9(2), 133-140.

Concentrations of $\mathrm{Cd}, \mathrm{Pb}, \mathrm{Ni}, \mathrm{Cu}, \mathrm{Zn}$ and $\mathrm{S}$ were detcrmined in 16 moss species collected from 9 localities in southern Spitsbergen (mostly within the Hornsund region). Two species, Sanionia uncinata and Hylocomium splendens, were objects of more thorough studies. In Sanionia uncinata the mean concentrations were $(\mu \mathrm{g} / \mathrm{g}): \mathrm{Cd}-0.59, \mathrm{~Pb}-7.07, \mathrm{Ni}-4.25, \mathrm{Cu}-6.01, \mathrm{Zn}-21.13$ and $\mathrm{S}-1,481$. Hylocomium splendens accumulated similar quantities of these clements. The concentrations of mctals and sulphur in mosses differed significantly $(p<0.05)$ from site to site, depending on geological and climatic conditions specific to the Arctic region. The effect of remote sources of pollution reaching Spitsbergen on the levels of heavy metal concentrations was taken into account, as well as the effect of local emissions from the Polish Polar Station. At 10-25 metre distances from the Station. the levels of heavy metals and sulphur werc 3-10 times higher than at a 300-metre distance.

Krystyna Grodzinska and Barbara Godzik, W. Szafer Institute of Botany, Polish Academy of Sciences Lubicz 46, 31-512 Kraków, Poland.

\section{Introduction}

The Arctic environment is influenced by chemical elements of both anthropogenic and natural origin and from remote as well as local sources (Jaworowski 1989). The Svalbard region is exposed to a greater atmospheric transport of inpurities from distant sources than some other Arctic areas (Rahn et al. 1983; Penkett 1984; Pacyna \& Ottar 1985; Ottar et al. 1986; Heintzenberg 1989; Jaworowski 1989). The island seems to be affected by airborne pollutants originating in western Europe and the Soviet Union and to a lesser extent in North America (Rahn \& Show 1982; Rahn 1984; Maenhaut et al. 1989). Local sources of pollution, e.g. mines, miners' colonies and polar stations (Krzyszowska 1985a), are thought to contribute only negligible quantities of pollutants compared with remote sources (Lannefors et al. 1983).

The extent of environmental pollution is often assessed by employing plants of various systematic groups as bioindicators (Grodziński \& Yorks 1981). Mosses have commonly been used as bioindicators of pollution by heavy metals (Rühling \& Tyler 1973, 1984; Rühling et al. 1987; Grodzińska 1978; Grodzińska et al. 1990) and, to a lesser extent, as indicators for sulphur compounds (Winner \& Atkinson 1987; Szarek \&
Chrzanowska in press). The aim of our study was to assess the degree of environmental pollution in a large area of southern Spitsbergen as well as the area closely surrounding the Polish Polar Station in the Hornsund area; as bioindicators, we employed various species of moss.

\section{Material and methods}

Sixteen species of mosses were collected in Arctic tundra ecosystems at 1-9 sites within an area of $30,000 \mathrm{~km}^{2}$ in southern Spitsbergen. Eight species were collected at 1-6 sites within 10 to 300 -metre distances west and east of the Polish Polar Station (Figs. 1 and 2). All the samples were taken at the beginning of June 1985 , immediately after snow melting. The unwashed mosses were separated into green and brown shoots and stored in paper bags. The material was dried to a constant weight at $85^{\circ}$. The samples were then wetdigested in a $4: 1$ mixture of concentrated spectral pure nitric $\left(\mathrm{HNO}_{3}\right)$ and perchloric $\left(\mathrm{HClO}_{4}\right)$ acids on a hot plate for 3 days until all organic matter was oxidized. The solution was evaporated to 1 $\mathrm{ml}$ and then diluted with distilled water to 50 $\mathrm{ml}$. Pyrex glassware was used for the chemical procedure. 


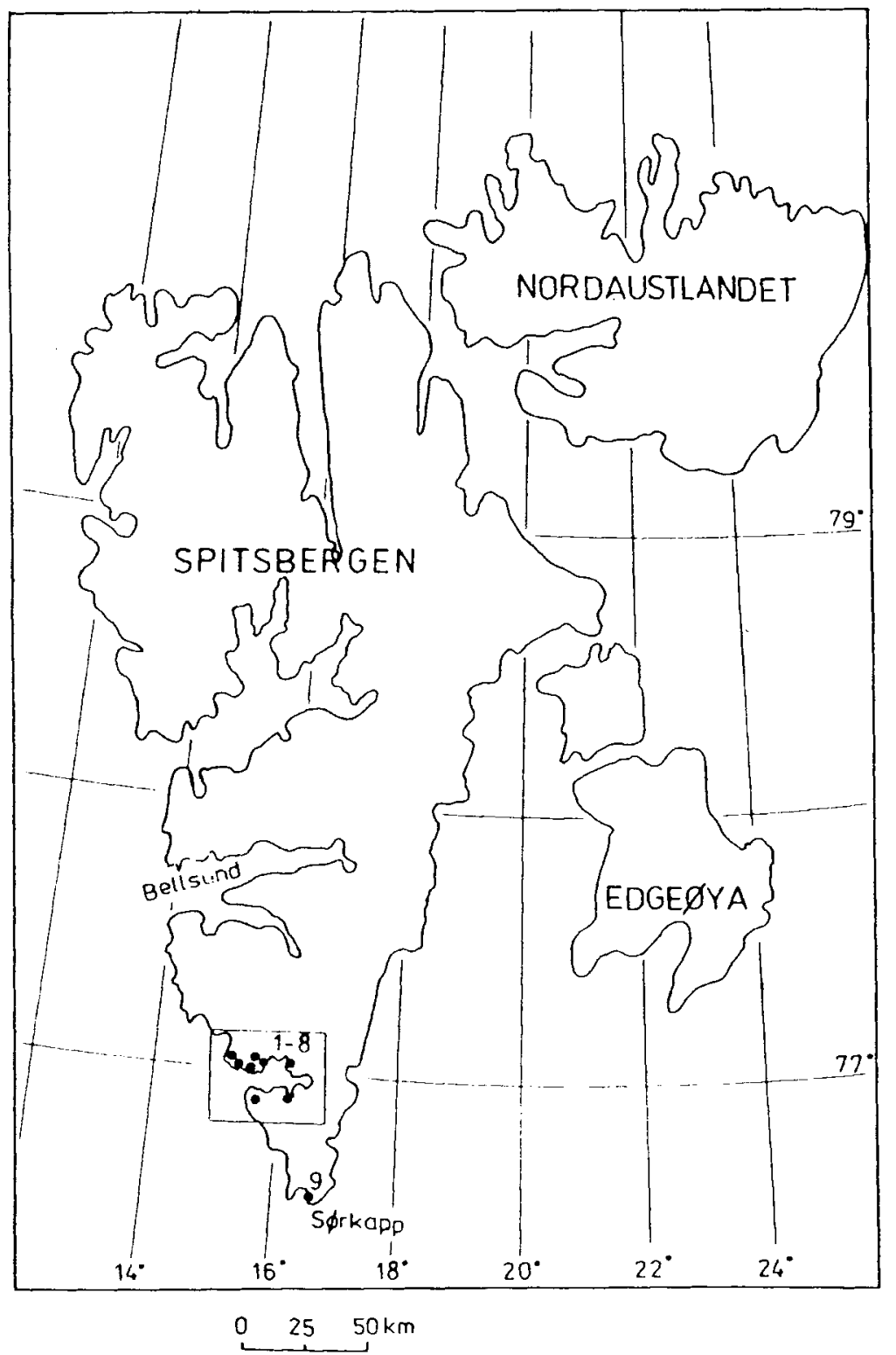

Fig. 1. Sites of moss sampling in southern Spitsbergen.

Heavy metal (Cd, $\mathrm{Pb}, \mathrm{Ni}, \mathrm{Cu}, \mathrm{Zn})$ concentrations were determined in the water solution by atomic absorption spectrophotometry (Varian Techtron A-1000). Total sulphur was determined by the Butters-Chenery method according to Nowosielski (1968).

Blanks were run in each series of samples. The concentrations of metals and sulphur in the blanks were $(\mu \mathrm{g} / \mathrm{g}): \mathrm{Cd}-09.01, \mathrm{Cu}-0.01, \mathrm{Fe}-0.3, \mathrm{Mn}-$ $0.0, \mathrm{Ni}-0.02, \mathrm{~Pb}-0.04, \mathrm{Zn}-0.1, \mathrm{Ca}-0.6, \mathrm{Mg}-$ 0.2 and $S-5$.

Nonparametric two-way variance analysis and H-test (Sokal \& Rohlf 1969) were used to estimate the differences between element concentrations in moss species from the various sites. 


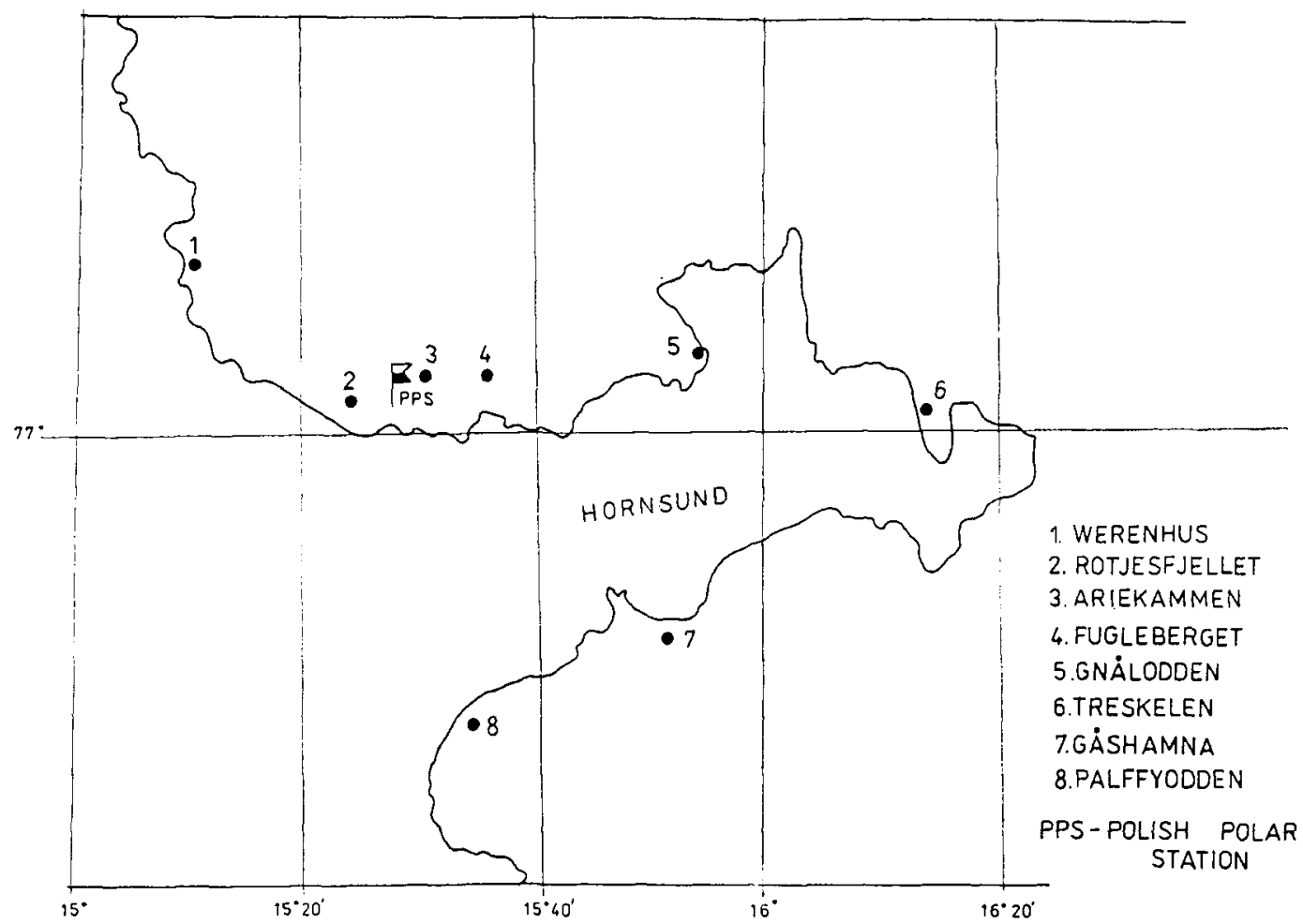

Fig. 2. Sites of moss sampling in the Hornsund area.

\section{Results}

\section{Heavy metal concentrations in mosses from southern Spitsbergen}

Considerable differences among concentrations were found for particular species (Table 1). The moss species can be divided into two groups as far as the accumulation of some chemical elements is concerned. Aulacomium palustre and A. turgidum, Hylocomium splendens, Sanionia uncinata and Tortula ruralis are good accumulators for heavy metals while Racomitrium lanuginosum, Polytrichum alpinum and Dicranum groenlandicum are not. The members of the first group show significant $(p<0.05)$ differences in heavy metal concentrations at different sites within southern Spitsbergen, whereas moss species of the second group show more homogeneous results (Table 2).

Two species (Hylocomium splendens and Sanionia uncinata), which accumulate rather large quantities of heavy metals were chosen for assessment of the extent of environmental pollution.
Sanionia is a very common species throughout the area. Hylocomium is much less common, but it was chosen because of its widespread use as a bioindicator of environmental pollution elsewhere.

The mean concentrations of heavy metals in Sanionia uncinata in southern Spitsbergen were as follows $(\mu \mathrm{g} / \mathrm{g}): \mathrm{Cd}-0.59, \mathrm{~Pb}-7.07, \mathrm{Ni}-4.25$, $\mathrm{Cu}-6.01$ and $\mathrm{Zn}-21.13$ (Table 3). Hylocomium splendens accumulates heavy metals at similar concentrations: $\mathrm{Cd}-0.66, \mathrm{~Pb}-6.54, \mathrm{Ni}-3.56$, $\mathrm{Cu}-6.08$ and $\mathrm{Zn}-23.80$ (Table 4).

The concentrations of heavy metals in both Sanionia uncinata and Hylocomium splendens varied among the sites (Tables 3, 4; Fig. 3). The highest quantities of cadmium in Sanionia uncinata were accumulated at the Gnålodden site, of nickel and copper at the Treskelen site, of zinc at a southernmost Sørkapp site, and of lead at the Palffyodden site (Table 3; Fig. 3). The least quantities of cadmium, zinc and copper were found at the Gåshamna site, of lead and nickel at the Werenhus site (Table 3; Fig. 3).

When the sites are arranged in order of increas- 
Table 1. Concentrations of heavy metals and total sulphur (ugg 'd wit) in mosses from southern Spitsbergen (valucs are means of $2-21$ (amples).

\begin{tabular}{|c|c|c|c|c|c|c|c|c|c|c|c|c|c|}
\hline \multirow[b]{2}{*}{ Species } & \multirow[b]{2}{*}{$\mathrm{n}$} & \multicolumn{2}{|c|}{$\mathrm{Cd}$} & \multicolumn{2}{|c|}{$\mathrm{Ph}$} & \multicolumn{2}{|c|}{$\mathrm{Ni}$} & \multicolumn{2}{|c|}{$\mathrm{Cu}$} & \multicolumn{2}{|c|}{$\mathrm{Zn}$} & \multicolumn{2}{|c|}{$\mathrm{s}$} \\
\hline & & $\overline{\mathrm{x}}$ & SD & $\bar{x}$ & SD & $\overline{\mathrm{x}}$ & SD & $\bar{x}$ & SD & $\hat{\mathrm{x}}$ & SD & $\overline{\mathrm{x}}$ & SD \\
\hline Aulacomnium palustre ( $\mathrm{Hedw}$ ) & & & & & & & & & & & & & \\
\hline $\begin{array}{l}\text { Schwacge. } \\
\text { Aulacomnium turgidum (Whlb.) }\end{array}$ & 6 & 0.83 & 0.18 & 6.69 & 1.42 & 8.31 & 5.41 & 13.98 & 13.07 & 29.62 & 5.33 & 903 & 220 \\
\hline Schwaegt. & 15 & 0.77 & 0.19 & 5.68 & 2.13 & 2.57 & 0.80 & 3.31 & 1.92 & 26.76 & 6.96 & 1081 & 247 \\
\hline Brachythecium turgidum (Hartm.) & & & & & & & & & & & & & \\
\hline $\begin{array}{l}\text { B.S.G. } \\
\text { Calliergon stramineum }\end{array}$ & 3 & 1.95 & 0.37 & 3.50 & 0.74 & 1.81 & 0.45 & 4.42 & 0.58 & 29.33 & 0.48 & 1168 & 314 \\
\hline Kindh. & 3 & 0.82 & 0.06 & +.03 & 0.77 & 7.29 & 0.45 & 6.11 & 0.00 & 29.07 & 1.27 & 1219 & 325 \\
\hline Dicranum grocnlandicum Brid. & 8 & 0.46 & 1.12 & 2.93 & 1.36 & 1.70 & 0.59 & 3.67 & 0.76 & 16.39 & 4.43 & 1190 & 282 \\
\hline Dicranum spadiceum Zett. & 8 & 0.59 & 0.21 & 5.70 & 2.16 & 2.41 & 0.45 & 3.02 & 1.03 & 17.19 & 5.22 & 1112 & 322 \\
\hline Ditrichum fexicaule (Schleich.) & & & & & & & & & & & & & \\
\hline $\begin{array}{l}\text { Hampe } \\
\text { Hyloconium splendens }\end{array}$ & 3 & 0.44 & 0.13 & 1.60 & 0.04 & 0.79 & 0.02 & 2.15 & 0.00 & 9.80 & 0.86 & 780 & 52 \\
\hline B.S.G. & 9 & 0.66 & 0.12 & 6.54 & 1.45 & 3.56 & 1.25 & 0.08 & 3.01 & 23.80 & 9.88 & 1103 & 297 \\
\hline Pleurozium schreberi Mitt. & 6 & 0.63 & 0.14 & $6 .(x)$ & 3.51 & 3.90 & 1.65 & 2.92 & 1.05 & 19.35 & 6.01 & 1224 & 368 \\
\hline Polytrichum alpinum Hedw. & 8 & 0.42 & 0.09 & $3.58^{\circ}$ & 1.87 & 2.33 & 0.71 & 4.34 & 0.40 & 18.69 & 3.19 & 1238 & 303 \\
\hline Polytrichum commune Hedw. & 3 & 0.26 & 0.04 & 0.94 & 0.28 & 1.71 & 0.21 & 4.76 & 0.58 & 24.01 & 0.32 & 1294 & 313 \\
\hline Racomitrium ericoides (Brid.) & & & & & & & & & & & & & \\
\hline Brid. & 3 & 0.82 & 0.07 & 7.05 & 1.30 & 12.56 & 0.56 & 17.69 & 1.80 & 42.87 & 2.31 & 1586 & 37 \\
\hline $\begin{array}{l}\text { Racomitrium lanuginosum } \\
\text { (Hedw.) Brid. }\end{array}$ & 18 & 0.31 & 0.09 & 4.86 & 2.20 & 2.35 & 0.87 & 2.31 & 1.91 & 13.04 & 4.94 & 561 & 164 \\
\hline $\begin{array}{l}\text { Sanionia uncinata Hedw. } \\
\text { Tomentypnum nitcons (Hedw }\end{array}$ & 21 & 0.59 & 0.13 & 7.07 & 4.49 & 4.25 & 2.53 & 6.01 & 4.52 & 21.13 & 4.98 & 1481 & 143 \\
\hline Loeske & 6 & 0.71 & 0.11 & 6.44 & 1.49 & 8.75 & 6.92 & 5.92 & 7.07 & 26.70 & 17.65 & 1256 & 41 \\
\hline $\begin{array}{l}\text { Tortula rurahs (Hedw) Gaertn.. } \\
\text { Mever at Scherb. }\end{array}$ & 12 & 0.85 & 0.40 & 5.22 & 1.76 & 3.57 & 0.84 & 6.90 & 3.30 & 31.74 & 14.21 & 1718 & 369 \\
\hline
\end{tabular}

ing concentrations of heavy metals, the list starts with the Gáshamna and Werenhus sites and ends with the Treskelen, Gnalodden and Palffyodden sites (Table 3).

\section{Total sulphur concentration in mosses from southern Spitshergen}

The concentrations of sulphur are highest in
Sanionia uncinata, Aulacomium turgidum and Hylocomium splendens and many times less in Racomitrium lanuginosum and Polytrichum alpinum (Tables 1, 3 and 4). There are statistically significant $(p<0.05)$ differences in sulphur concentrations in mosses between sites (Table 2). Sanionia, for example, accumulated the least sulphur on the Werenhus site, the most on the Ariekammen site (Table 3).

Tuble 2. Statistical analysis of the differences between heary metitls and total sulphur concentrations in moss species from various sites in southern Spitsbergen. ${ }^{* *}$

\begin{tabular}{|c|c|c|c|c|c|c|}
\hline Species & $\mathrm{Cd}$ & $\mathrm{Pb}$ & $\mathrm{Ni}$ & Cu & $Z n$ & $S$ \\
\hline Aulacomnium turgidum & $0.003^{*}$ & $0.2199^{\mathrm{ns}}$ & $0.006^{*}$ & $0.0000^{*}$ & $0.000^{*}$ & $0.000^{*}$ \\
\hline Dicranum groenlandicum & $0.6(4)^{n}$ & onst: & $0.346^{\mathrm{n}}$ & $0.044^{*}$ & $0.011^{*}$ & $0.007^{*}$ \\
\hline Hylocomium splendens & $0.041^{\star}$ & $0.0\left(12^{*}\right.$ & $0.021^{*}$ & $0.044^{*}$ & $0.181^{1 \mathrm{ss}}$ & $0.001^{*}$ \\
\hline Polvtrichum alpinum & $0.362^{\mathrm{m}}$ & $0.138^{\mathrm{n}}$ & $0.038^{\circ}$ & $0.223^{\mathrm{ns}}$ & $0.982^{\mathrm{ns}}$ & $0.022^{*}$ \\
\hline Racomitrium lanuginosum & $0.457^{\mathrm{m}}$ & $0.105^{n-}$ & $0.008^{*}$ & $0.103^{n}$ & $0.044^{*}$ & $0.0006^{*}$ \\
\hline Sanionia uncinata & $0.021^{*}$ & $0.138^{\mathrm{m}}$ & $0.005^{*}$ & $0.007^{*}$ & $0.008^{*}$ & $0.000^{*}$ \\
\hline Tortula ruralis & $0.001^{*}$ & $0.0077^{\circ}$ & $0.000^{*}$ & $0.000^{*}$ & $0.000^{*}$ & $0.011^{*}$ \\
\hline
\end{tabular}

$p<0.115$

-. Seven mos species occurring in more than two sites were used for statistical analysis (cf. Table 1). 
Table 3. Concentrations of heavy metals and total sulphur $\left(\mu \mathrm{gg}{ }^{\mathrm{l}} \mathrm{d} . \mathrm{wt}\right)$ in Sanionia uncinata collected from 8 sites in southern Spitsbergen. Values are means of 3 samples cach.

\begin{tabular}{|c|c|c|c|c|c|c|c|c|c|c|c|c|}
\hline \multirow[b]{2}{*}{ Site } & \multicolumn{2}{|c|}{$\mathrm{Cd}$} & \multicolumn{2}{|c|}{$\mathrm{Pb}$} & \multicolumn{2}{|r|}{$\mathrm{Ni}$} & \multicolumn{2}{|c|}{$\mathrm{Cu}$} & \multicolumn{2}{|c|}{$\mathrm{Zn}$} & \multicolumn{2}{|c|}{$\mathrm{S}$} \\
\hline & $\bar{x}$ & SD & $\bar{x}$ & $\mathrm{SD}$ & $\bar{x}$ & SD & $\overline{\mathrm{x}}$ & SD & $\bar{x}$ & SD & $\overline{\mathrm{x}}$ & SD \\
\hline Wercnhus & 0.526 & 0.07 & 2.36 & 0.34 & 1.60 & 0.04 & 2.85 & 0.61 & 20.95 & 0.91 & 1330 & 0 \\
\hline Rotjesfjeltet & 0.679 & 0.08 & 4.99 & 1.08 & 2.37 & 0.06 & 2.73 & 0.58 & 17.16 & 1.51 & - & \\
\hline Fugleberged/ & & & & & & & & & & & & \\
\hline Arickammen & 0.723 & 0.12 & 9.48 & 1.55 & 5.06 & 0.39 & 9.51 & 0.00 & 21.98 & 1.24 & 1626 & 64 \\
\hline Gnălodden & 0.817 & 0.05 & 12.0 & 2.11 & 3.30 & 0.27 & 4.27 & 0.00 & 26.17 & 0.31 & - & \\
\hline Treskelen & 0.582 & 0.05 & 5.12 & 0.54 & 8.88 & 0.24 & 14.96 & 1.54 & 25.00 & 1.92 & 1600 & 52 \\
\hline Gäshamna & 0.406 & 0.04 & 3.88 & 0.55 & 2.07 & -0.22 & 2.05 & 0.00 & 12.38 & 1.14 & 1370 & 0 \\
\hline Palffyodden & $0.5(1) 2$ & 0.08 & 16.26 & 0.52 & 6.76 & 0.11 & 6.84 & 0.84 & 22.83 & 0.35 & - & \\
\hline Sørkapp & 0.576 & 0.05 & 4.60 & 0.39 & 4.67 & 0.55 & 5.60 & 0.70 & 27.06 & 1.56 & - & \\
\hline Average & 0.598 & 0.13 & 7.07 & 4.49 & 4.25 & 2.53 & 6.01 & 4.52 & 21.13 & 4.98 & 1481 & 143 \\
\hline
\end{tabular}

Concentrations of heavy metals and sulphur in the surroundings of the Polish Polar Station

Within 10 to 25 metre distances from the Polish Polar Station the concentrations were several times higher than those at the Ariekammen site which is about $1 \mathrm{~km}$ distance from the Station; the concentrations were also higher than the mean concentrations in Sanionia uncinata on 8 sites of southern Spitsbergen (Table 5). Most remarkable were the differences in concentrations of zinc $(10 \times)$, copper $(6 \times)$ and lead $(3 \times)$ between sites within $10-25 \mathrm{~m}$ of the Station and the Ariekammen site. The differences were less pronounced in the cases of nickel and cadmium (Table 5). Around the station Sanionia uncinata had higher amounts of heavy metals than $\mathrm{Hyl}$ ocomium splendens (Table 5).

At 150-300 metre distances from the Station, the heavy metal concentrations did not differ from those at the Ariekammen site and the 8 sites of southern Spitsbergen (Tables 3-5).

The total sulphur concentrations in mosses collected in the entire 10 to 300 metre zone near the
Station were uniform and did not differ from those found at the Ariekammen site (Tables 3-$5)$.

\section{Discussion}

The different concentrations of heavy metals in mosses noted from the various sites in southern Spitsbergen situated several kilometres to several tens of kilometres suggest local causes of such differences.

Spitsbergen is an area with very diversified geology. The southern part of Spitsbergen consists mainly of Precambrian formations of Hoeckla Hoek, accompanied by rocks of Carbon, Permian and Devonian age (Smulikowski 1965). In the fjord Hornsund there are quartz, ankerite, and ankerite-quartz ore-bearing veins. These veins often contain pyrite and chalcopyrite; less often they contain pirotyne, galena, sphalerite. limonite, cuprite, malachite and azurite (Birkenmajer \& Wojciechowski 1964; Wojciechowski

Table 4. Concentrations of heavy metals and total sulphur ( $\left.\mu \mathrm{g} \mathrm{g}^{-1} \mathrm{~d} . \mathrm{wt}\right)$ in Hylocomium splendens collected from 3 sites in southern Spitsbergen. Values are means of 3 samples cach.

\begin{tabular}{|c|c|c|c|c|c|c|c|c|c|c|c|c|}
\hline \multirow[b]{2}{*}{ Site } & \multicolumn{2}{|c|}{$\mathrm{Cd}$} & \multicolumn{2}{|c|}{$\mathrm{Pb}$} & \multicolumn{2}{|c|}{$\mathrm{Ni}$} & \multicolumn{2}{|c|}{$\mathrm{Cu}$} & \multicolumn{2}{|c|}{$\mathrm{Zn}$} & \multicolumn{2}{|c|}{$\mathrm{s}$} \\
\hline & $\overrightarrow{\mathrm{x}}$ & SD & $\overline{\mathbf{x}}$ & SD & $\bar{x}$ & SD & $\overline{\mathrm{x}}$ & $\mathrm{SD}$ & $\overline{\mathrm{x}}$ & SD & $\bar{x}$ & SD \\
\hline Rotjesfjellet & 0.75 & 0.12 & 6.4 & 0.62 & 3.63 & 0.45 & 4.08 & 0.00 & 17.77 & 3.09 & 730 & 43 \\
\hline Ariekammen & 0.518 & 0.03 & 5.05 & 0.43 & 2.37 & 0.06 & 4.08 & 0.00 & 36.2 & 2.86 & 1400 & 34 \\
\hline Fuglcberget & 0.719 & 0.08 & 8.18 & 0.72 & 4.69 & 1.43 & 10.10 & 0.00 & 17.45 & 1.00 & 1180 & 40 \\
\hline Average & 0.662 & 0.13 & 6.54 & 1.45 & 3.56 & 1.25 & 6.08 & 3.47 & 23.80 & 9.88 & 1103 & 297 \\
\hline
\end{tabular}




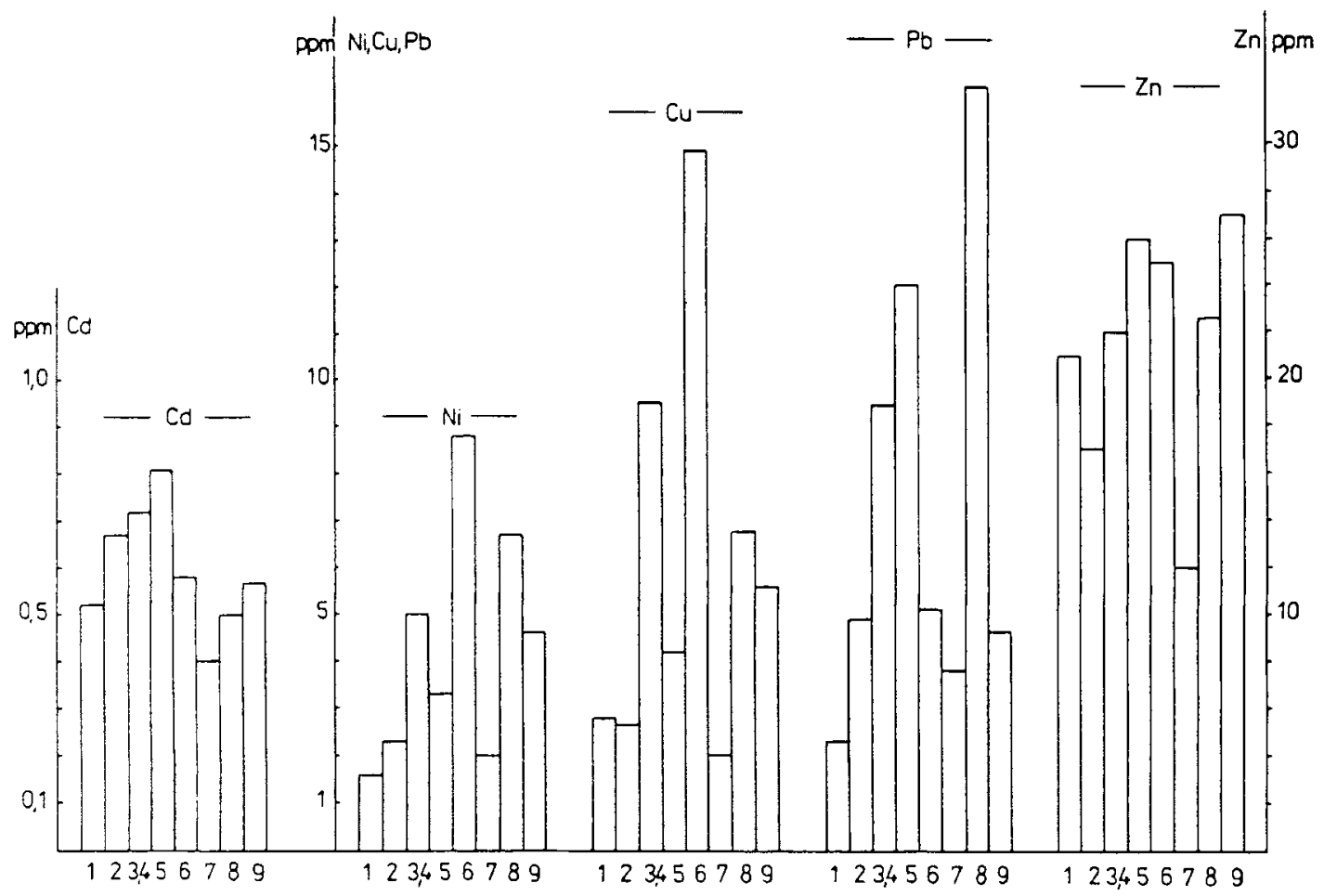

Fig. 3. Concentration of $\mathrm{Cd}, \mathrm{Ni}, \mathrm{Cu}, \mathrm{Pb}$ and $\mathrm{Zn}$ (ppm d.wt.) in Sanionia uncinata collected from different sites in southern Spitsbergen: Sec Fig. 2 for locations of sites 1-8; site $9=$ Sørkapp

1964). The rocks of Fugleberget, Ariekammen, Gåshamna and Palfyodden, where most of samples of mosses were collected, are rich in pyrite and chalcopyrite (Wojciechowski 1964). These rocks contain higher concentrations of heavy metals, mainly $\mathrm{Fe}$ and $\mathrm{Cu}$, sometimes also $\mathrm{Zn}, \mathrm{Cd}$ and $\mathrm{Pb}$.

Rather high concentrations of heavy metals (except $\mathrm{Pb}$ ) in Svalbard soils are reported by Steinnes (1984) and Thomas (1986).

Table S. Concentrations of heavy metals and total sulphur ( $\mu \mathrm{g}^{-1} \mathrm{~d} . \mathrm{wt}$ ) in Sanionia uncinata (S) and Hylocomium splendens (H) collected in various distances from the Polish Polar Station. Values are means of 3 samples each.

\begin{tabular}{|c|c|c|c|c|c|c|c|c|c|c|c|c|c|}
\hline \multirow[b]{2}{*}{ Site } & & \multicolumn{2}{|c|}{$\mathrm{Cd}$} & \multicolumn{2}{|c|}{$\mathrm{Ph}$} & \multicolumn{2}{|c|}{$\mathrm{Ni}$} & \multicolumn{2}{|c|}{$\mathrm{Cu}$} & \multicolumn{2}{|c|}{$\mathrm{Zn}$} & \multicolumn{2}{|c|}{$S$} \\
\hline & & $\bar{x}$ & $\mathrm{SD}$ & $\bar{x}$ & $\mathrm{SD}$ & $\ddot{x}$ & $\mathrm{SD}$ & $\bar{x}$ & $\mathrm{SD}$ & $\bar{x}$ & $\mathrm{SD}$ & $\bar{x}$ & $\mathrm{SD}$ \\
\hline \multirow{2}{*}{$10 \mathrm{~mW}$} & $\mathrm{~S}$ & 1.15 & 0.14 & 20.18 & 0.00 & 6.04 & 0.45 & 36.90 & 2.30 & 226.0 & 50.90 & 1450 & 0 \\
\hline & $\mathrm{H}$ & 0.67 & 0.09 & 15.56 & 0.38 & 5.55 & 0.77 & 14.24 & 0.64 & 96.9 & 1.21 & 1146 & 35 \\
\hline \multirow{2}{*}{$70 \mathrm{~mW}$} & $S$ & 0.56 & 0.05 & 8.98 & 0.79 & 3.93 & 0.52 & 8.66 & 1.22 & 73.9 & 8.98 & - & \\
\hline & 11 & 0.68 & 0.04 & 11.75 & 2.10 & 3.85 & 0.32 & 8.66 & 1.22 & 47.3 & 1.10 & 1136 & 11 \\
\hline \multirow{2}{*}{$150 \mathrm{~mW}$} & $\$$ & 0.44 & 0.12 & 8.98 & 1.11 & 4.53 & $0 .(0)$ & 7.44 & 0.00 & 46.2 & 6.36 & 1663 & 35 \\
\hline & 11 & 0.35 & 0.00 & 8.19 & 0.00 & 2.88 & 0.49 & 9.90 & 1.56 & 45.7 & 4.11 & - & \\
\hline \multirow{2}{*}{$3(x) \mathrm{m} \mathrm{W}^{\prime}$} & $S$ & 11.41 & 0.06 & 6.04 & 0.89 & 3.15 & 0.64 & 4.98 & 0.00 & 21.3 & 0.77 & - & \\
\hline & $\mathrm{H}$ & - & - & - & - & - & - & - & - & - & - & - & \\
\hline \multirow{2}{*}{$25 \mathrm{mE}$} & $S$ & 11.45 & 0.156 & 21.11 & 2.03 & 4.5 .3 & 0.00 & 28.04 & 2.39 & 76.9 & 0.87 & 1360 & 69 \\
\hline & $H$ & -- & - & - & 一 & - & - & - & - & $\ldots$ & - & - & \\
\hline \multirow{2}{*}{$1001 \mathrm{mE}$} & $\mathrm{S}$ & 0.52 & 0.07 & 5.54 & 0.97 & 3.14 & 0.86 & 7.77 & 0.47 & 145.9 & 5.16 & - & \\
\hline & $H$ & - & - & - & - & - & - & - & - & - & - & - & \\
\hline
\end{tabular}


In the Arctic areas, superficial rocks are weathered into fine particles due to the erosive action of air and water. In southern Spitsbergen, the snow cover persists for $9-10$ months. During the short 2-3-month summer, abundant waters from melting snow flow over the surface of rocks and moss mats. They carry a variety of rock fragments, minerals, and chemical compounds which can easily be absorbed by plants (Krzyszowska 1985b). Mosses have no epidermis and cuticula, therefore their cell walls are easily penetrable for metal ions (Tyler 1971, 1972). It may be supposed that there is a relationship between the levels of at least some of the heavy metals in mosses and the substrate in the southern part of Spitsbergen. The chemical analyses within this project covered only mosses; the chemical composition of soil and rocks was not determined. No data are therefore given here which could document correlations between the concentrations of heavy metals in mosses and substrate in individual sites in southern Spitsbergen.

Many published studies (Rahn et al. 1983; Heintzenberg 1989; Jaworowski 1989) state that air pollutants from industrialized parts of the Northern Hemisphere reach the Arctic regions by way of long distance transboundary transport. These pollutants enter Arctic tundra via precipitation. Mosses, the main components of this tundra, have no organs for uptake of minerals from substrate; they obtain minerals, as well as pollutants, from the atmosphere from precipitation and dry deposition (Tyler 1971). Hence it may be expected that high concentrations of heavy metals and sulphur in the mosses of southern Spitsbergen are, at least, in part, caused by the long range transboundary transport of pollutants in gaseous and particulate form.

Our data for heavy metal concentrations in mosses from southern Spitsbergen have been compared with similar data from Sweden, Iceland, and Greenland (Rühling et al. 1987). The levels of lead and zinc in Spitsbergen mosses are several times lower than those found in Sweden, but similar to those from Iceland and Greenland. However, the copper concentration in mosses from Spitsbergen was similar to that in Sweden and 2-3 times less than copper concentrations in mosses from Iceland and Greenland. The mosses from southern Spitsbergen contained considerable quantities of cadmium and nickel, higher than found in mosses from Scandinavia, Iceland and Greenland.
Our results are in a good agreement with the heavy metal concentrations in plant material collected in Spitsbergen and reported by Jaworowski (1967), Thomas (1986), and Ottar et al. (1986).

Ruhling et al. (1987) demonstrated decreasing heavy metal concentrations from south to north in Scandinavia as an effect of the transboundary transport of pollutants from western Europe. Lead, zinc and copper follow this pattern in southern Spitsbergen; cadmium, nickel and sulphur do not.

Staaland et al. (1983) found much higher concentrations of metals in reindeer forage plants (lichen, bryophytes, forbs) from Svalbard than in plants from continental Norway. Jaworowski (1989) suggests that this might be due to the greater availability of metals in Svalbard soils, a result of intensive weathering processes.

The level of heavy metals found in mosses collected within a 10-300 metre radius around the Polish Polar Station at Hornsund proved that the chemical effects from the station are local and present no threat to the Arctic tundra ecosystems. Similar conclusions have been reached by Krzyszowska (1985a). According to her assessment, the anthropogenic impact of the Station is rather insignificant, affecting no more than 3.5 hectares.

Because of specific climatic conditions and the diversified chemistry of the substrate in the Arctic regions, the mosses should be applied as indicators of air pollution by heavy metals only with caution.

Mosses in the close surroundings of local sources of pollution, for example polar stations, in uniform geological conditions can prove to be very sensitive indicators of local changes in the atmosphere.

Sanionia uncinata, Hylocomium splendens and other species representing the first group of mosses distinguished in this study can be regarded as good indicators of pollution originating from local sources. The other group (among others Racomitrium canescens and Polytrichum alpinum) shows less diversity in heavy metal concentrations between sites in southern Spitsbergen, being less affected by substrate composition. This group may be used for monitoring pollutants originating from distant, transboundary sources.

Acknowledgements. - This work was supported by the Polish Academy of Sciences, programme CPBP 03.03. 


\section{References}

Birkenmajer K. \& Wojciechowski, J. 1964. On the age of orebearing veins of the Hornsund area. Vestspitsbergen. Studia Geol. Pol. 11. 179-184.

Grodzińska, K. 1978: Mosses as bioindicators of heavy metal pollution in Polish National Parks. Water. Air and Soil Pollution 9. 83-97.

Grodzińska. K., Szarek. G. \& Godzik. B. 1990: Heavy metal deposition in Polish National Parks - changes during ten years. Water, Air and Soil Pollution 49, 409-419.

Grodziński. W. \& Yorks. T. P. 1981: Species and ecosystem level bioindicators of airborne pollution: An analysis of two major studies. Water. Air and Soil Pollution 16. 33-53.

Heintzenberg. J. 1989: Arctic Haze: Air pollution in polar regions. Ambio $18.50-55$.

Jaworowski. Z. 1967: Stable and radioactive lead in environment and human body. Nuclear Energy Information Center. Warsaw, Report No. NEIC-RR-29. 1-181

Jaworowski. Z. 1989: Pollution of the Norwegian Arctic: A review. Norsk Polurinstitull Rapportserie $55.93 \mathrm{pp}$.

Krzyszowska, A. J. 1985a: Tundra degradation in the vicinity of the Polish Polar Station. Hornsund. Svalbard. Polar Research 3. 247-252.

Krzvszowiska. A. J. 1985b: Chemistry of the freshwater of the Fugleberget drainage basin. Pol. Polar Res. 6. 341-347.

Lannefors. H., Heintzenterg. J. \& Hansson. H.Ch. 1983: A comprehensive study of physical and chemical parameters of the Arctic summer acrosol: results from the Swedish expedition Y'mer-80. Tellus 35 B. 40-54.

Macnhaut, W., Cornille. P., Pacyna, J. M. \& Vitols. V. 1989 Trace element composition and origin of atmospheric aerosols in the Norwegian Arctic. Atmos. Environ 231111, 25512570.

Nowosielski. O. 196x: Metody oznaczania potrzeb nawozenia Warszawa PWRiL his pp.

Ottar, B. Y., Gottas. Y.. How. O.. Iversen. T.. Joranger, E.. Oehme, M. Pacyna. J. Semb. A.. Thomas. W. \& Vitols. V. 1986: Air pollutants in the Arctic. N/LU OR: 30/86.180.

Pacyna. J. M. \& Ottar. B. 1985: Transport and chemical composition of the summer aerosol in the Norwegian Arctic. Atmos. Environ. 19. 21149-2120.

Penkett. S. A. 1984: Implications of arctic air pollution. Nature 3/1. 299.

Rahn. K. A 1984: Who's polluting the Arctic? Natural History 9. 1-4.
Rahn, K. A. \& Show. E. G. 1982: Sources and transport of arctic pollution aerosols: a chronicle of six years of ONR research. Naval Research Rev. 1982 34, 3-26.

Rahn, K. A., Lewis, N. F., Lowenthal. D. H. \& Smith, D. L. 1983: Noril'sk only a minor contributor to Arctic hazc. Nature. 306, 459-461.

Rühling, A., Rasmussen, L., Pilegaard, K., Måkinen, A. \& Steinnes. E. 1987: Survey of atmospheric heavy metal deposition in the Nordic countrics in 1985. Nord 21, 1-44.

Rühling. A. \& Tyler, G. 1973: Hcavy metal deposition in Scandinavia. Water, Air and Soil Pollution 2, 445-455.

Rühling. A \& Tyler. G. 1984: Recent changes in the deposition of heavy metals in northern Europe. Water, Air and Soil Pollution 22, 173-180.

Smulikowski W. 1965. Petrology and some structural data of Jover metamorphic formations of the Hoeckla Hoek succession in Horsnund. Vestspitsbergen. Studia Geol. Pol. 18 , $1-107$

Sokal. R. R. \& Rohlf, F. J. 1969: Biometry. Freeman and Company. San Francisco. $776 \mathrm{pp}$.

Staaland. H., Brattbakk, I., Ekern, K. \& Kildemo, K. 1983 Chemical composition of reindeer forage plants in Svalbard and Norway. Holarctic Ecology 6. 109-122.

Steinnes. E. 1984: Heavy metal pollution of natural surface soil due to long-distance atmospheric transport. Pp. 115-122 in Yaron. B., Dagan. G., Goldshmid, J. (eds.): Pollutants in Porous Media. Springer Verlag, Berlin.

Szarek. G. \& Chrzanowska, E. in press: Sulphur content in the mosses of Polish National Parks-changes during ten years. Acta Soc. Bot. Pol.

Thomas. W. 1986: Accumulation of airborne trace pollutants in Arctic plants and soil. Wat. Sci. Tech. 18, 47-57.

Tyler G. 1971: Moss analysis: A method for surveying heavy metal deposition. Pp. 129-132 in Englund. H. M. \& Berry, W. T. (eds.): Proceedings of the 2 nd International Clean Air Congress, Washington $D C$.

Tyler G. 1972: Heavy metals pollute nature. may reduce productivity. Ambio 1. 57-59.

Winner, W. E. \& Atkinson. C. 1987: Annual absorption of gaseous air pollutants by mosses and vascular plants in diverse habitats. Pp. 427-438 in Hutchinson, T. C. \& Meema, K. M. (eds.): Effects of atmospheric pollutants on forests, wetlands and agricultural ecosystems. NATO ASI series vol. 6,16 Springer Verl. London-Paris-Tokyo.

Wojciechowski J. 1964: Ore-bearing veins of the Hornsund area. Vestspitsbergen. Studia Geol. Pol. 11, 173-177. 